field of student health, and of Desmond O'Neill, psychiatrist to Queen Charlotte's and Chelsea Hospital for Women.

Next came the record of our Loyal Address on the occasion of the Queen's Silver Jubilee and of Her Majesty's gracious reply.

Then Dr Markowe began his supplementary report by announcing the results of the ballots for the election of certain Officers, as follows:

Dean: Dr T. H. Bewley.

Sub-Deans: Drs C. P. B. Brook, S. B. Mahapatra, E. B. O. Smith.

Dr J. L. Grammer had been elected unopposed as Editor of the foumal, and the Registrar, Dr Markowe, and Treasurer, Dr Warren, remain in office.

Dr Markowe went on to refer to discussions which had taken place with the Privy Council office concerning the proposed revision of the Bye-laws, in which good progress was being made. There had also been the usual 'annual meeting' session with the DHSS. The most interesting news emerging from this is that there is to be an official survey of patients discharged from psychiatric hospitals into the community, which the College will support.

The College's Special Committee is looking further into the implications of the Normansfield Inquiry and into ways of protecting the interests both of sick doctors and of their patients.
At short notice, evidence is to be given to the Department of Education on corporal punishment in schools, and comments are being prepared for other official bodies on 'mercy killing' and on children in hospital.

There has been a proposal to set up a Group for Biological Psychiatry, and this is being investigated.

After the reading of the report, the Meeting paid tribute to the work of its two retiring Officers-the Dean, Professor Rawnsley and the Editor, Dr E. H. Hare.

Next we proceeded to the election of Honorary Fellows. They were our own Ken Rawnsley; Lord Rayne, a staunch supporter and benefactor of the College; Sir Henry Yellowlees, now Chief Medical Officer at the DHSS, bringing back to the College a name which has been prominent in British psychiatry for over a century; our good friend from Norway, Ørnulv Ødegard, promoted from Corresponding Member (as it used to be); and Dr Seymour. Kety, of McLean Hospital in Massachussetts, whose name symbolizes biological psychiatry and who is to be the Maudsley Lecturer next year. Appropriate citation speeches were given for all these, which will be reported in summary in the Minutes.

No resolutions had been proposed by individual members, and there was no discussion on either domestic or political matters.

Alexander Walk

\title{
ANNUAL SUBSCRIPTIONS: A REMINDER
}

Annual subscriptions for 1977 were due on I January last. Members are reminded of the ByeLaws, which state:

\section{Section VIII (5)}

Members of the College whose subscriptions are more than twelve months in arrear shall not be entitled to vote or to enjoy any of the privileges of Membership of the College, except the right to use after their names the designation prescribed by these Bye-Laws. Their privileges shall be restored when, but not before, all arrears have been paid.

\section{Section VIII (6)}

Any Affiliate, Inceptor or Corresponding Associate who, his subscription being more than twelve months in arrear, shall have failed to make payment thereof after a special application to him by the Treasurer, shall be reported by the Treasurer

to the Council which may thereupon direct that his name be removed from the register.

If your subscription for the current year is still outstanding please send forthwith a cheque for the appropriate amount to the Honorary Treasurer, 17 Belgrave Square, London SWIX 8PG, quoting your reference number, if you know it.

The annual subscription rates are as follows:

\begin{tabular}{llr} 
Fellows & (United Kingdom) & $£ 50.00$ \\
Fellows & (Overseas) & $£ 40.00$ \\
Members & (United Kingdom) & $£ 35.00$ \\
Members & (Overseas) & $£ 25.00$ \\
Affiliates & (United Kingdom) & $£ 20.00$ \\
Affiliates & (Overseas) & $£ 15.00$ \\
Inceptors & $£ 10.00$ \\
Corresponding Associates & $£ 10.00$ \\
Retired Members before 31.12.75 & $£ 4.00$ \\
\multicolumn{2}{c}{ after 1.1.76 } & $£ 10.00$
\end{tabular}

